\title{
The Curtiss Flying Boat
}

\author{
Description of an Improved Type of Hydro-aeroplane
}

By Frank T. Searight

THE latest and biggest wonder in the world of aviaTion was tried out by Glenn $\mathbf{H}$. Curtiss last month at his San Diego, Cal., public aviation school, and has proved a success beyond the expectations of its invent or. This new hydro-aeroplane is known as the "Curtiss Flying Boat.'

The "Flying Boat" resembles the Curtiss hydro-aeroplane, now in use in the navy, only in that it has a similar set of planes and that the boat is like the float of the latter to some extent.

It differs in that it carries a passenger as well as an aviator in the boat, is of 60 horse-power, has a speed of fifty miles an hour in water and sixty miles an hour in air, contains bulkheads fore and aft, has an automatic starter, fuel gage, bilge pump, and spray hood engine (not shown in photo), and that it is driven through a clutch and chain transmission extending to twin propellers.

The new machine differs from the old hydro-aeroplane in that it is a "headless" biplane with only a rear control. It also has two propellers placed in front of the planes, and driven by chains from the motor, instead of one behind on the engine. The "Flying Boat" is capable of standing any wind or wave that any boat of its size will stand. The boat part of it, which tapers at each end, is 20 feet long by 30 inches wide, and $41 / 2$ feet deep. has a cockpit in the center $21 / 2$ square feet in size.

The advantages claimed for the "Flying Boat" are its safety, quickness to rise from the water, and that it is comfortable and can be.operated like a boat.

The new air-water craft was tried out for balance and speed on water and worked perfectly. Mr. Curtiss stated, however, that work on it so far has been ex perimental, and further experiments will le made soon before it will be considered a finisked type.

The try-out was on the Spanish Bight, a part of San Diego Bay, which has made the Curtiss camp an ideal place for experiments with such craft; outdoor conditions have been so good there the winter through that the "Flying Boat" was set up in a canvas hangar on the beach, and thus easily launched.

New Points About the Kola Nut HE kola nut is much esteemed by the natives in the parts of Africa where it grows, on account of its valuable stimulant and medicinal properties, and it occupies a large place in African legends, as well as in ceremonies and cults. All these tribes have been aware of its stimulating properies from time immemorial, and it is also used as a remedy for marsh fever and many other maladies. M. P. Guerin, of the Paris Colloge of Pharmecy, brings out a number of curious customs in which the kola nut figures. It is used as a pledge of friendship or affection, as an offering to fetish men, and also as money or for paying tribute. In the Bambara and other regions, a young man sends a lasket of white and red kola nuts to the father of a young woman whom he desires to marry, and if the father consents, he keeps all the nuts, but if not, he keeps the white ones and returns the red. The natives offer the white kola nuts as a gift to foreigners, as the white nuts are held in greater esteem than the red, but if they have none of the white they offer the red. In the whole of the Soudan region the kola nut is a symbol of friendsh'p, and as it is an article of luxury, the act of offering it as a gift is article of luxury, the act of offering it as a gift is taken as a mark of the wealth of che giver. Eicing
the kola nut together is a sign of friendship, and it the kola nut together is a sign of friendship, and it
would be a great offense to refuse to do this. Treaties, vows or compacts are made binding in the same way. The kola tree is much respected, and M. Chevalier cites as an example the fact that he wished to secure some

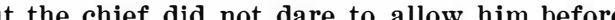
assembling some of the old men and other principal

persons, and even then none of them would pluck the flowers. They allowed him to do so, but said that this would bring him bad luck. Among the Bagas, tree is planted at each birth or notable occasion. In the Diorugu region when a chief goes through the cere mony of naming his child, he plants a kola tree, an this afterward belongs to the child. When a tree planted on the tomb of a chief, his son possesses it, an

M. A. Chevalier figures the yearly production of French West Africa at 5,000 tons, and to this is to be added the production of the English colonies. While the fresh nut is an object of commerce in different African regions, only the dried nut is imported to Europe, at the rate of about 1,000 tons a year. A native in Africa will eat 600 or 700 kola nuts in a year, making about 25 pounds weight. This amount is limited only because the kola is rare and has a high price, owing to the difficulty of transporting it in these regions. The development of railroads would be of great benefit to the kola trade. Experiments have recently been made to determine what principles cause the stimulating effect. In the fresh nut M. Goris found in addition to caffeine, two new principles, kolatine and kolateine, and he shows conclusively that the dried nut has very little power to sustain the vitality of the system and prevent fatigue, such as is displayed by the fresh kola. The kola tree bears some resemblance to a fruit tree, and has handsome white flowers. A tree will bear an average of 600 nuts a year under good conditions. As the result of the above researches we are to conclude that the dried kola nut should be no longer im. ported, especially as the fresh nuts can be easily transported in fiber packing. The nuts can be kept fresh by putting them in layers in 1 or 2-pound tin boxes, and they will thus last for several months. Messrs. Goris and Arnould, of Paris, have found a very good method of sterilizing the fresh powder so that -it will keep indefinitely.

\section{A Sleeping Fish}

$S^{\text {OME curious habits in a fish have been }}$ by the French zoölogist, B. Romeis. The fish in question, which bears the name Paratilapia multicolor, was kept in an aquarium containing suitable seaweed, and observed through several seasons.

Side view of flying boat, showing position of man and motor.

The female fish places the eggs in pockets in her mouth, and keeps them there until they hatch. After hatching, the fry is thrown out into the water in the morning, but toward evening the young fish come back to the mother's mouth, inside of which they spend the night.

A resting condition resembling sleep was also observed. Ordinarily these fish rest near the bottom of the water. But after the eggs are laid the female seeks the surface of the water, so that at times her back fins were actually out in the air. When at the surface, she pressed her side fins close against the body, and remained quite motionless for as much as two hours at a stretch. With the exception of very slight movements of the gill covers, there was nothing to indicate that the animal was still alive.

Dr. Romeis supposes that the advantage in this habit lies in the fact that the female having eaten no food for a long time (during the breeding season) and being obliged to economize the reserve fats in her body, avoids motion as much

Glenn $H$. Curtiss and some of his pupils. THE LATEST AMERICAN HYDRO-AEROPLANE

such a tree is supposed to grow more rapidly. In othe cases when a native wishes to communicate with a dead person of his family, he pours water on the tomb in which kola nuts had been placed. The trees, at least, in the coast region, are usually owned by individual and pass to others by heritage like other property, but among the Dans and Dyolas only the chiefs and principal persons on own them. On the lower Ivory coast the trees are the object of a sort of ancestral cult, and are not allowed to be cut, being held in great respect. Although the stimulating properties of the kola nut are well known, there has been some doubt up to the present as to what principles are the cause of this action. Besides, as the nuts are imported from Africa they are apt to arrive in the dry state, and the dry nut has but little value. The natives consume large quantities of the fresh nut, but will not use the dried nuts. as possible. Floating near the surface is perhaps connected with the fact that here the fish can get sufficient oxygen with the least amount of exercise.

\section{Milan's New Water Supply System}

NASMUCH as springs are too long a distance
from Milan, that city has lately reorganized its water supply system by boring artesian wells on the spot and going down to 260 feet depth. At present there are upward of 70 artesian wells bored and a good water supply is thus afforded. This accomplishment led to the building of a number of water works for feeding into the city mains, and eight stations are now operating and nine are building for this purpose. For operating some of the pumping plants, Diesel oil enpines are used, while others use steam engines Electric motors are also employed for a number of them 